Polonistyka. Innowacje

Numer 1, 2015

DOI: 10.14746/pi.2015.1.1.6

\title{
Seweryna Wysłouch
}

Uniwersytet im. Adama Mickiewicza, Poznań

\section{Kronika wypadków milosnych wcale się nie zestarzala}

\section{"The chronicle of love affairs" did not grow old}

\begin{abstract}
The author of this article analyzes The Chronicle of Love Affairs by Tadeusz Konwicki (1974) and shows that it can be still used at school. The main problems of this novel (youthful love, suicide, the identity of the protagonists) provide an opportunity to discuss current topics. The novel allows to expand the historical and literary knowledge of information in the field of Konwicki's creativity, romantic tradition, literature of private homelands, as well as assimilate theoretical concepts, such as oniric poetics and film adaptation.
\end{abstract}

Keywords: Konwicki, love, suicide, identity, the literature of private homelands, oniric poetics, film adaptation.

Tadeusz Konwicki Kronikę wypadków miłosnych (1974) - obok Dziury w niebie (1959) i Zwierzoczlekoupiora (1969) - zaliczył do nurtu „rekreacyjno-smętkowego”, pisanego, jak mówił, „dla przyjemności czytelników i mojej” (Nowicki 1990, 176). Powieść ta powinna, moim zdaniem, trafić na ławy szkolne. Może sprawić także przyjemność licealistom, przełamać ich niechęć do słowa drukowanego i obowiązkowej lektury. A przede wszystkim warto byłoby wykorzystać niedocenianą zawartość problemową i edukacyjną tego utworu.

Widzę następujące problemy do omówienia: 1) miłość przed maturą; 2) samobójstwo - problem psychologiczny, społeczny i kulturowy; 3) Wilno i dolina Wilenki jako „mała ojczyzna" Konwickiego; 4) poetyka oniryczna; 5) Kronika wypadków miłosnych a adaptacja filmowa Andrzeja Wajdy (1986). Wyróżnione problemy można potraktować skrótowo, można je też rozbudować, korzystając ze wskazanej literatury przedmiotu. 


\section{Miłość przed maturą}

Powieść Konwickiego przedstawia jeden zasadniczy wątek: miłość Wicia do Aliny. Miłość od pierwszego wejrzenia, która ogarnia go całkowicie, powoduje, że działa jak w gorączce. Śledzi dziewczynę, wagaruje, pod wpływem emocji całymi nocami czatuje pod jej domem i zapomina o nadchodzącej maturze. Nauka zupełnie nie wchodzi mu do głowy, dla swej miłości gotów wszystko poświęcić. Nie obchodzi go świat zewnętrzny, nawet wojna, o której wszyscy mówią. Nie zwraca uwagi na protesty matki, lekceważy ostrzeżenia przyjaciół. Odrzuca propozycję Engla, by - jak dawniej - uczyć się razem. A jednocześnie jest głęboko przekonany, że będzie sławnym lekarzem i „wielkim profesorem”. Oblana matura to dla niego niezasłużona klęska. W rozmowie z Aliną mówi:

\footnotetext{
jak to się mogło stać? Dlaczego Bóg, los, przypadek mnie uderzył w łeb obuchem. Dlaczego tak podle, znienacka, bez uprzedzenia? [...] dlaczego mnie właśnie musiała się przydarzyć taka koszmarna kraksa?” (Konwicki 2006, 213-214).
}

Problem do dyskusji: „dlaczego”? Oczywiście najprościej można odpowiedzieć: bo się nie uczył. Ale sądzę, że sprawa jest bardziej skomplikowana, dotyczy także atmosfery w domu rodzinnym. Matka wpajała w niego przekonanie, że jest w czepku urodzony i najlepszy, że musi być sławnym doktorem i wielkim profesorem. I takie też miał on sam ambicje. Ale przecież tytuły i sława nie przychodzą ot, tak sobie, trzeba mieć do zawodu predyspozycje, a przede wszystkim na sukces ciężko pracować. I tego motywu tutaj zabrakło. Wicio jest niedojrzały i nieodpowiedzialny. Nie widzi swoich błędów, obwinia wszystkich: Boga, los, przypadek, tylko nie siebie. Oblana matura jest dla niego końcem świata, nie słucha Aliny, która rozsądnie radzi mu odczekać i zdawać egzamin dojrzałości powtórnie. Dla niego jedyne wyjście z sytuacji to śmierć i tak powstaje myśl o wspólnym samobójstwie.

Można by zadać pytanie, czy gdyby nie oblana matura i próba samobójcza związek Wicia i Aliny byłby trwały? Wszak planowali po maturze ślub i ucieczkę „,do któregoś z miast uniwersyteckich". Można się zabawić w wymyślanie alternatywnych losów bohaterów tej powieści.

\section{Samobójstwo - problem psychologiczny, społeczny, kulturowy}

Problematyka samobójstwa w omawianym utworze jest sygnalizowana wielokrotnie ${ }^{1}$. Już na początku powieści poznany przez Wicia w pociągu tajemniczy biedak rzuca się pod

\footnotetext{
${ }^{1}$ Samobójstwa i próby samobójcze to motywy częste w powieściach Konwickiego np. Dziura w niebie, Sennik wspótczesny, Mała apokalipsa.
} 
koła. Ojciec Wicia powiesił się w lesie z powodu oskarżenia o defraudację, a po wielu latach sam Wicio, stary i chory, żeby skrócić swoje cierpienia, kładzie się na torach. Tymczasem próba samobójcza Wicia i Aliny różni się od trzech pozostałych przedstawionych w powieści - bohaterowie są piękni i młodzi, Alina jest w ślubnej sukni. Samobójstwo przekształca się w poetyckie misterium nad rzeką... Aż kusi, żeby poszukać literackich wzorów - od Romea i Julii poczynając.

Ale czy to wszystko znaczy, że romans Wicia i Aliny jest przedstawiony z patosem? $\mathrm{Z}$ pełną aprobatą narratora? Otóż nie. Ironicznym akompaniamentem są bowiem wtrącone w opowiadaną historię informacje gazetowe o krwawych dramatach miłosnych, zabójstwach, kradzieżach i samobójstwach wśród biedoty miejskiej - kucharek, pokojówek, studentów. Kolażowe wstawki pokazują niejako drugą stronę medalu, sygnalizują dystans wobec „romansu z wyższych sfer” i zderzają go ze wstydliwą rzeczywistością.

Samobójstwo jest skomplikowanym problemem natury psychologicznej, społecznej i kulturowej. Na podstawie powieści możemy wiele powiedzieć o motywach, które do niego doprowadziły, jak psychiczne załamanie Wicia i obsesja śmierci u Aliny, która stale powtarza, że umrze młodo. Ale w powieści samobójstwo to także problem społeczny. Rodzice Aliny chcą udaremnić ich związek i Engel tak uzasadnia ich stanowisko: „Oni pamiętają i wszyscy pamiętają [...]. Jesteś synem wisielca” (Konwicki 2006, 179). Samobójcza śmierć w opinii społecznej jest czymś hańbiącym. Rodzina samobójcy żyje z piętnem, które ma dopiero zmazać wymarzona kariera Wicia. Dlatego też matka pragnie, żeby Wicio był wielkim lekarzem, bo „wtedy ludzie wszystko zapomną” (Konwicki 2006, 30), a on sam mówi o odkupieniu ,niezawinionej winy ojca” (Konwicki 2006, 213). Odium samobójczej śmierci uważanej za haniebną, wyraźnie ciąży nad rodziną bohatera. Dlaczego?

Samobójstwo w naszej kulturze było uważane za najcięższy grzech, przekreślający zbawienie, bo skierowany przeciwko miłosierdziu Bożemu. I tu otwiera się płaszczyzna do badań porównawczych: jak samobójstwo traktowano na Dalekim Wschodzie (japońskie harakiri), jak traktowali je starożytni (np. Katon czy Petroniusz, którego przedstawił Sienkiewicz w Quo vadis?). Kategoryczny zakaz samobójstwa wprowadziły dopiero wielkie religie monoteistyczne: chrześcijaństwo, judaizm, islam. Bezwzględnie potępił je św. Augustyn, opierając się na ,prawie wiecznym”, które według niego musi być respektowane. Św. Augustyn zdeprecjonował starożytnych bohaterów odbierających sobie życie ze wzniosłych pobudek i za wzór postawił Hioba, pokornie znoszącego zesłane przez Boga cierpienia (Chwin [2013], 19-70). Od czasów średniowiecza „czarną” ikoną 
samobójstwa stał się Judasz, który zdradził Chrystusa za 30 srebrników, a później nękany wyrzutami sumienia odebrał sobie życie (Chwin [2010], 51-66). Wszystkie te wątki można rozwinąć $\mathrm{w}$ przygotowanych dłuższych wypowiedziach albo w uczniowskich referatach. Doktryna potępiająca samobójstwo, które skazuje nieszczęśnika na wieczne potępienie, znalazła odbicie w zwyczajach i w panującym w Europie porządku prawnym. Obowiązywał zakaz pochówku samobójcy w poświęconej ziemi, zakaz odprawiania za jego duszę ceremonii pogrzebowych, unieważnienie jego testamentu, konfiskata majątku. Ze starych encyklopedii można wyczytać, że karano nie tylko niedoszłych samobójców ${ }^{2}$, ale także zwłoki tych, którzy zdołali odebrać sobie życie. Zmianę w doktrynie katolickiej zasygnalizował dopiero w latach 90. XX wieku Katechizm Kościoła Katolickiego, w którym potępiony został tylko czyn samobójczy. Natomiast nieszczęśliwy człowiek za sprawą miłosierdzia Bożego może jednak dostąpić zbawienia (Katechizm Kościoła Katolickiego 1994, 518).

Samobójstwa wśród młodzieży szkolnej są osobnym problemem, którym też trzeba by się zająć, tym bardziej że ich statystyki niepokojąco rosną. Dlaczego uczniowie odbierają sobie życie? Z powodu niepowodzeń szkolnych? Braku akceptacji w grupie rówieśniczej? Przemocy psychicznej i fizycznej? Jak walczyć z tym złem?

\section{„Mała ojczyzna” Konwickiego}

Kolejnym tematem, jaki nasuwa Kronika wypadków miłosnych, jest „mala ojczyzna” Konwickiego - Litwa, a ściślej miejsce jego urodzenia, do którego pisarz wielokrotnie w swoich utworach powraca: otoczona lasem Kolonia Wileńska, leżąca w głębokiej dolinie meandrycznie wijącej się rzeki Wilenki i połączona koleją z Wilnem. Tam właśnie toczy się akcja powieści ${ }^{3}$. Ale narrator raz po raz przerywa opowieść i snuje osobiste, liryczne dygresje na temat Litwy, jej mieszkańców i obyczajów. Oto jedna z nich:

W tamtych czasach Litwa była nieokreślonym obszarem geograficznym, niejasną formacją etniczną, niezdefiniowaną sferą kulturową. W tamtych czasach Litwa była gwałtowną letnią burzą albo może raczej wnętrzem wygasającego wulkanu, który umierał w ostatnich spazmach. Litwa była wtedy wielkim zachodzącym słońcem, co zostawia po sobie smugi dziwnie pięknych świateł i resztki dogasającej tęczy.

\footnotetext{
${ }^{2}$ We Francji karano niedoszłych samobójców do Wielkiej Rewolucji Francuskiej, w Anglii - do 1961 roku (Innes 1999, 38).

${ }^{3}$ Podobnie jak akcja Dziury w niebie. Motywy doliny, rzeki, lasu wielokrotnie wracają w powieściach Konwickiego (Tomaszewski 1991).
} 
Dożywała ona swoich dni w polszczyźnie wileńskiej, w pieśniach białoruskich, w przysłowiach litewskich, trwała jeszcze w ginącym obyczaju, w wybujałych chorobliwie na chwilę charakterach, w powolnej i gęstej dobroci ludzkiej. Odchodziła w niepamięć przez krajobraz pełen szalonych kwiatów, słodkich zapachów ziół, budzących tajemniczą grozę borów. Odchodziła w niezrozumianą i zapomnianą co dzień dawność przez sadzawki rzewnego smutku, przez jeziora melancholii, przez meandryczne rzeki przeczuć.

Jacy byli ci ludzie o zlitewszczonych nazwiskach i spolszczonych duszach, o spolszczonych nazwiskach i zlitewszczonych duszach? Jacy byli ludzie modlący się do Jehowy i do prawosławnego Boga, lękający się Dewajtisa i Peruna, Czorta i Lucyfera, Zaduszek i Sądnego Dnia? Jacy byli ci potomkowie Tatarów, Polaków, Żydów, Litwinów, Białorusinów, Karaimów i wszystkich innych ludzi, których prześladowania, krzywda, nieszczęścia zagnały w północne puszcze i rojsty?

Rozbiegli się po świecie. Żyją samotnie w pojedynkę. Zapomnieli mowy, która była mową kilku języków. I tylko czasem zaskoczy w cudzym mieście śród obcych liter jesienny wiatr litewski i błyśnie raptem złe dobro albo dobre zło w mieszczańskiej głuszy, i odezwie się czasem w sercu normalności jakaś duszna i wabiąca nienormalność.

Umiera ziemia guślarzy i wróżbitów, umiera ziemia proroków i mesjaszy, co już nie zdążyli zbawić świata. W tym wiecznym pochodzie zwycięskiej cywilizacji, w niewiadomą przyszłość zdeptano łąki, spalono bory, otruto embriony geniuszu.

Kochajmy tyle Litwy, ile jej zostało. (Konwicki 2006, 121-122)

Dygresja ma charakter elegijny. Narrator wspomina bujną litewską przyrodę, która ginie pod naporem zwycięskiej cywilizacji oraz ludzi różnych wiar i różnych narodowości, którzy tam mieszkali, a później się rozproszyli po świecie. Boleje nad rozpadem dawnej wspólnoty, zanikiem polszczyzny wileńskiej, zmianą obyczaju. Elegijny charakter manifestują „wodne” metafory oddające nastrój narratora: sadzawki smutku, jeziora melancholii, rzeki przeczuć. Natomiast Litwa charakteryzowana jest jako potężny żywioł: burza letnia; wnętrze wygasajacego wulkanu, który umierał w ostatnich spazmach; zachodzace słońce, co zostawia po sobie smugi dziwnie pięknych światet i resztki dogasajacej tęczy. Przenośnie te podkreślają piękno krainy, ale zarazem wieszczą jej rychły kres, schyłek, umieranie. Poprzez typ metafory i charakter liryczny narracja Konwickiego wyraźnie nawiązuje do tradycji romantycznej. Warto też wspomnieć, że Konwicki przeniósł na ekran Mickiewiczowskie Dziady - jest autorem scenariusza i reżyserem filmu Lawa. Opowieść o „Dziadach” Adama Mickiewicza (1989). 
Poetycka charakterystyka Litwy znajduje potwierdzenie w fabule utworu, która rozgrywa się głównie w plenerze. Ale przede wszystkim manifestuje wielonarodowość tego regionu. Oprócz polskiego establishmentu (luksusowy dom Aliny, w którym mówi się po francusku, ojciec, zasłużony lekarz wojskowy, auto do własnej dyspozycji) oraz ubogich rodzin polskich, jak rodzina Wicia, która z trudem składa pieniądze na jego naukę, są jego przyjaciele - Rosjanin Lowka i niemiecka rodzina pastora Bauma - Engel i Greta. Najciekawszy jest ten ostatni wątek, pokazujący konflikt pokoleń: Engel nie czuje się Niemcem, zasymilował się w polskim środowisku, chce nawet zmienić sobie imię i nazwisko, by zatrzeć ślady obcego pochodzenia. Bardziej wnikliwa jest Greta, zadaje pytanie, kim oni w rzeczywistości są: nie są już Niemcami, a Polakami - też nie. Otwiera się tu pole do dyskusji. Kim są Greta i Engel? Niemcami? Polakami? Problem jest ważny i stale aktualny, szczególnie po otwarciu europejskich granic, w czasach masowej emigracji. Dotyczy bowiem tożsamości narodowej, asymilacji w nowym środowisku i społecznej akceptacji obcych.

Dociekliwy czytelnik może badać Mickiewiczowskie tropy w stylistyce i opisach Kroniki wypadków miłosnych. Może także wziąć mapę Wilna i śledzić opisywane realia Górę Zamkową, Górę Trzech Krzyży, park, Ostrą Bramę, wymienione w powieści ulice. Wędrówka po mieście, połączona z materiałem ikonicznym (zabytki Wilna i widoki okolicy) doskonale zaprezentowałaby „małą ojczyznę” Konwickiego. A temat można poszerzać, daje do tego okazję historia Litwy - przedwojenna, wojenna i powojenna, pozostała twórczość Konwickiego (szczególnie Rojsty, 1947 i Bohiń, 19974), a przede wszystkim kontekst literacki - nurt zwany literaturą ojczyzn prywatnych, który w latach 60 . XX wieku stał się niezwykle popularny.

Nurt ten zainicjowany został przez pisarzy emigracyjnych, którzy wracali we wspomnieniach do dzieciństwa, spędzonego na kresach dawnej Rzeczpospolitej i traktowanego jako bezpowrotnie utracona Arkadia. Kresy ukazywane były jako wielonarodowe i wielokulturowe, wraz z nimi ginie po wojnie kulturowy dorobek przeszłości.

Literatura ojczyzn prywatnych jest zróżnicowana, dotyczy bowiem wielu regionów: Wileńszczyzny (Czesław Miłosz, Józef Mackiewicz), dawnej Galicji (Leopold Buczkowski, Andrzej Kuśniewicz, Julian Stryjkowski), a także Gdańska, małej ojczyzny pisarzy urodzonych po wojnie (Paweł Huelle, Stefan Chwin). Najważniejszym utworem tego nurtu jest Dolina Issy Czesława Miłosza (1955), który do powieści wprowadził wątek autobiograficzny. Przedstawił dojrzewanie bohatera, wyrastającego wśród litewskiej przyrody, który poznaje

\footnotetext{
${ }^{4}$ Bohiń przenosi akcję w wiek XIX, Rojsty przedstawiają partyzantkę antybolszewicką na Wileńszczyznie w 1944 r., w której Konwicki brał udział.
} 
siebie i świat, a największym jego przeżyciem jest wtajemniczenie w miłość i śmierć. Wyjazd do Wilna i opuszczenie doliny to jednocześnie wygnanie z raju. Powieść Miłosza zafascynowała Tadeusza Konwickiego, który nie tylko był autorem scenariusza filmowego, ale wyreżyserował Dolinę Issy (1982). I jego utwory - szczególnie Dziura w niebie i Zwierzoczłekoupiór - korzystają z Miłoszowego wzoru powieści inicjacyjnej. Powtarzalność kresowych tematów i motywów naraziła Konwickiego na zarzut, że pisze wciąż jedną i tę samą książkę. Czy słusznie?

Literatura ojczyzn prywatnych może być kolejnym obszarem polonistycznych penetracji.

\section{Poetyka oniryczna}

Warto zwrócić uwagę, że Kronika wypadków miłosnych nie przypomina tradycyjnej, XIX-wiecznej powieści, typu Nad Niemnem, Marty czy Bene nati Orzeszkowej, gdzie wydarzenia ukazywane są ,po porządku”. Oto po samobójstwie Wicia i Aliny narrator przedstawia starego, cierpiącego na nieuleczalną chorobę Witolda, który decyduje się na akt samobójczy. Epizod, który ma miejsce po wielu latach, w dawnej powieści byłby epilogiem, tutaj poprzedza powrót młodego Wicia do przytomności.

Inna jest także kategoria narratora. Nie jest to już trzecioosobowy, abstrakcyjny narrator, który maskuje się i udaje, że go nie ma. Narrator Konwickiego manifestuje swoją obecność przez liryczne dygresje, które przywołują kresową przeszłość i czasy przedwojenne. Mówi o świętach wielkanocnych, koniach, samolotach, o młodości i grzechu - inaczej postrzeganych niż dzisiaj. Nazywa się nawet bogiem, co prawda „okaleczonym”, bo odcięto mu boską świadomość, boski wzrok i słuch (Konwicki 2006, 89-90). Ale to on opowiada, subiektywizuje i liryzuje narrację.

Najistotniejsze jest to, że Konwicki zrywa z realistycznym sposobem przedstawienia. Wprowadza bowiem do powieści postacie o niejasnym statusie ontologicznym, jak na przykład postać nieznajomego, który dwukrotnie rozmawia z Wiciem (raz nawet przychodzi do niego w nocy). Nie tylko zna przeszłość (pokazuje drzewo, na którym powiesił się jego ojciec), ale dokładnie wie, co się wydarzy w przyszłości. Kim więc jest? Sobowtórem Wicia, starszym od niego o kilkadziesiąt lat? Nie wiadomo.

Zakłócenia chronologii, motywy telepatii, snu, „widmowe” postacie pozwalają mówić o poetyce onirycznej. 


\section{Powieść a film}

Tadeusz Konwicki był powieściopisarzem i reżyserem filmowym, ale jego filmy to dzieła autorskie, oryginalne (Ostatni dzień lata, Zaduszki, Salto, Matura, Jak daleko stą, jak blisko). Scenariusze pisał na podstawie cudzych utworów, które przenosił na ekran, jak Dolinę Issy czy Lawę. Swoich utworów nie adaptował - jedynym wyjątkiem jest Kronika wypadków miłosnych (1986). Razem z reżyserem filmu, Andrzejem Wajdą, napisał scenariusz i nawet zagrał w tym filmie.

Jak wygląda adaptacja Kroniki wypadków miłosnych? Co znalazło się w filmie, a z czego autor zrezygnował i dlaczego? Co dodał?

Przede wszystkim dodana została rama: film rozpoczyna motto z Pana Tadeusza o kraju lat dziecinnych, a kończy elegijny gest autora, który wśród płonących na cmentarzu zniczy konstatuje: ,już nie ma krainy mojego dzieciństwa”. Rama sygnalizuje to, co dla twórców jest ważne: powrót do przeszłości i fascynację urodą Litwy. Toteż wyeksponowany został wątek miłosny, piękno krajobrazu i wielokulturowość regionu. Wicio i Alina podczas spaceru zaglądają nie do kościoła katolickiego (jak w powieści), ale do cerkwi, gdzie trwa ceremonia żałobna (widzą tam modlącego się Lowkę). Na ulicach i na dworcu spotykają wielu Żydów w tradycyjnych ubiorach, przystają pod oknem chederu. Scenografia podkreśla różnice kulturowe (ascetyczny dom pastora Bauma, secesyjny salon sióstr Puciatówien). Dbałość o realia, a także chęć przechytrzenia cenzury widoczna jest także w nazwie miejscowości, wymalowanej na szyldzie kolejowym, który obwieszcza: „Kolonia W.” (zamiast nieprawomyślnej, naruszającej sojusze „Kolonii Wileńskiej”).

W procesie przekładu dzieł epickich na ekran redukcja fabuły jest koniecznością, bo wszystkiego w dwie godziny pokazać się nie da. Dlatego pominięte zostały mniej istotne wątki np. ścigany przez policję Wołodko, który odnalazł parę samobójców (a tym samym ocalił im życie), czy też ujeżdżający na motorze pan Henryk. Ale obok tych oczywistych redukcji usunięte zostało to, co mogłoby zburzyć nastrój „rekreacyjno-smętkowy”, a więc wszelkie „historie niskie” relacjonowane przez międzywojenne gazety i cytowane w powieści ${ }^{5}$. Usunięty został także rozbudowany w utworze wątek śmierci samobójczej. Nie ma biedaka rzucającego się pod pociąg ani idącego w jego ślady starego Witolda. Nawet informacja o samobójstwie ojca Wicia, o którym napomyka matka, a wprost mówią: Nieznajomy, Engel, Wicio, a także Alina, została w filmie całkowicie pominięta. Skutkiem tego wyolbrzymione ambicje Wicia nie mają społecznej motywacji.

\footnotetext{
${ }^{5}$ Według B. Gizy w scenariuszu Kroniki... był prolog zawierający migawki z ówczesnej prasy i procesów sądowych (Giza 2007, 229-230).
} 
Czy to oznacza całkowitą akceptację postępowania Wicia? Brak dystansu wobec wydarzeń? Otóż dystans wprowadza rozbudowana rola Nieznajomego, który towarzyszy Wiciowi w pociągu, obserwuje go na spacerze z Aliną, w tajemniczy sposób wchodzi do jego domu i ze schowka wyjmuje ukrytą broń. A przede wszystkim trzykrotnie z nim rozmawia. Najważniejsza różnica między filmem i powieścią polega nie tylko na stałej obecności Nieznajomego, ale na tym, że rolę Nieznajomego gra sam Konwicki. Jest to znakomity chwyt, który wprowadza żywioł autobiograficzny do filmu. Sam pisarz wraca do krainy swojego dzieciństwa, zaznacza swoją obecność i sugeruje, że wszystko, co przedstawia, jest jego osobistym punktem widzenia. Wspomina przeszłość, której już nie można zmienić - można ją tylko zaakceptować.

Film Wajdy bardzo konsekwentnie eksponuje to, co sugeruje filmowa rama: kraj lat dziecinnych, jego urodę i wielokulturowość. Pokazuje przeżycia i niepokoje wieku młodzieńczego, i atmosferę tamtych lat. Może dziś razić obraz „Polski mocarstwowej” sugerowany przez reżysera poprzez natrętnie powracające sekwencje „ułańskie” (wojskowe ćwiczenia, przemarsze i manewry). Ale nie ulega kwestii, że stanowi odrębne, autonomiczne dzieło i że uprościł problematykę powieści Konwickiego.

$* * *$

Wydana 40 lat temu Kronika wypadków miłosnych wcale się nie zestarzała, problemy w niej poruszane nadal są aktualne. Powieść daje okazję do dyskusji nad postępowaniem młodzieżowych bohaterów, a także do poszerzenia wiedzy historycznoliterackiej i teoretycznej. Natomiast wybór ciekawych i aktywizujących form pracy z uczniami zależy od inwencji i pomysłowości nauczyciela.

\section{Bibliografia}

Aries Philippe, 1989, Człowiek i śmierć, przeł. Bąkowska E., Warszawa.

Chwin Stefan, [2013], Samobójstwo i „,grzech istnienia”, Gdańsk.

Chwin Stefan, [2010], Samobójstwo jako doświadczenie wyobraźni, Gdańsk.

Czapliński Przemysław, 1994, Tadeusz Konwicki, Poznań.

Czermińska Małgorzata, 2000, Centrum i kresy w prozie pisarzy urodzonych po wojnie, w: Czermińska M., Autobiograficzny trójkąt. Świadectwo, wyznanie, wyzwanie, Kraków. 
Giza Barbara, 2007, „Litewski tryptyk”- o scenariuszach wedtug „Doliny Issy”, „Dziadów” $i$ „,Kroniki wypadków miłosnych”, w: Giza B., Między literatura a filmem. O scenariuszach filmowych Tadeusza Konwickiego, Warszawa, s. 206- 238.

Hadaczek Bolesław, 1993, Kresy w literaturze polskiej XX wieku, Szczecin.

Innes Brian, 1999, Granice śmierci, przeł. Bernacki M. i Krzak-Ćwiertnia E., Warszawa.

Janion Maria, 1991, Tam gdzie rojsty. Przypadek romantycznego mediumizmu, w: Janion M., Projekt krytyki fantazmatycznej, Warszawa.

Jarzębski Jerzy, 1992, Exodus (ewolucja obrazu kresów po wojnie), w: Jarzębski J., W Polsce czyli wszędzie, Warszawa.

Konwicki Tadeusz, 2006, Kronika wypadków miłosnych, Warszawa.

Nasalska Anna, 1985, Formuła nostalgii. O sposobach kształtowania świata przedstawionego w prozie T. Konwickiego, w: Święch J., Modele świata i człowieka, Lublin.

Nowicki [Bereś] Stanisław, 1990, Pół wieku czyśćca. Rozmowy z Tadeuszem Konwickim, Warszawa.

Tomaszewski Marek, 1991, Magiczna triada Tadeusza Konwickiego, „Pamiętnik Literacki”, z. 3 .

Trybuś Krzysztof, Kałążny Jerzy, Okulicz-Kozaryn Radosław (red.), 2007, Kresy dekonstrukcja, Poznań.

Wiegandt Ewa, 1997, Literackie formy świadomości kresowej, w: Rzewuska E. (red.), Swoi i obcy w literaturze i kulturze, Lublin.

Seweryna Wysłouch - prof. dr hab.; emerytowany pracownik Instytutu Filologii Polskiej Uniwersytetu Adama Mickiewicza w Poznaniu. Autorka prac z zakresu prozy polskiej XX w.: Proza Michała Choromańskiego (1977), Problematyka symultanizmu $w$ prozie (1981); z dziedziny semiotyki literatury i sztuk plastycznych: Literatura a sztuki wizualne (1994), Literatura i semiotyka (2001); Wyprzedaż semiotyki, pod red. M. Brzóstowicz-Klajn i B. Kaniewskiej (2011), a także z dydaktyki literatury (współautorka Poetyki stosowanej $(1978,1987,2000)$. 